\title{
Application of moderately haloalkaliphilic nonsymbiotic diazotrophs of Lonar lake to saline soils
}

\author{
Butale S.V., Raut A.A.* and Sawant T.B. \\ ${ }^{*}$ P.G. Department of Microbiology, Yashwantrao Chavan college of Science, Karad, \\ Vidyanagar, Karad, 415 124. MS, India, 09960094720, 09762408507, avinashraut@aol.in.
}

\begin{abstract}
India is an agriculture based country and most of the Indian economy relies on agriculture. Western Maharashtrian soil is rich in humus which ensures better yield to the cash crops. Asymbiotic nitrogen fixing microorganisms play an important role in converting atmospheric nitrogen to ammonia in such soils to increase its fertility. But unfortunately many hectares of soil in this region are deposited with salts which render the land barren. Most of the agricultural land in India has become barren due to accumulation of excessive salts. Predominant nitrogen fixing bacteria in salt deposited soils find it difficult to fix atmospheric nitrogen due to high $\mathrm{pH}$ and salinity. Keeping this drastic situation in view, it was thought to isolate moderately haloalkaliphilic nonsymbiotic diazotrophs from Lonar Lake which is rich in salts and alkalinity. Lonar Lake is saline and alkaline lake formed due to meteorite impact some 52,000 years ago. Primary studies were carried to apply the same isolated diazotrophs into such salt deposited barren soil by pot experiments. Six nonsymbiotic diazotrophs isolated from Lonar Lake were applied on saline soils during pot experiments conducted in the polyhouse. Physical characters of the plants grown in pots, morphological characteristics, pesticide resistance potential and tolerance of the obtained isolates to various $\mathrm{NaCl}$ concentrations are presented in this paper.
\end{abstract}

Keywords: - agriculture, nonsymbiotic, diazotrophs, meteorite, haloalkaliphilic.

\begin{abstract}
Introduction
India is an agriculture based country and most of the Indian economy relies on agriculture. Western Maharashtrian soil is rich in humus which ensures better yield to the cash crops. But unfortunately many hectors of soil in this region are deposited with salts which render the land barren. Nonsymbiotic nitrogen fixing bacteria fix atmospheric nitrogen independently and convert it into ammonia which increases soil fertility and plant productivity [1]. Salinity in soil is developed due to accumulation of excessive salts and predominant nitrogen fixing bacteria in salt deposited soils find it difficult to fix nitrogen due to high $\mathrm{pH}$ and salinity [1]. Keeping this drastic situation in view it was thought to apply haloalkaliphilic nonsymbiotic diazotrophs from Lonar Lake to saline soils. Lonar Crater situated in the village Lonar (Lat. 19058', Long. 76034') in Buldhana District of Maharashtra State, India is the only one in the world formed by meteorite impact in basaltic rock. Formed some 52,000 years ago, it is today a closed basin lake that is saline and alkaline, rich in carbonates and bicarbonates [2]. Photograph 1: A view from the eastern rim of hypervelocity meteorite impact Lonar Crater Lake. Primary pot culture studies were carried out by applying moderately haloalkaliphilic nitrogen fixing bacteria from Lonar Lake to saline soils. Pesticide resistance potential of the isolates and tolerance of the same to various $\mathrm{NaCl}$ concentrations was also studied [3].
\end{abstract}

\section{Materials and Methods}

Halotolerant nonsymbiotic nitrogen fixers from Lonar lake soils were cultivated on modified Ashby's nitrogen free mannitol solid medium $(\mathrm{pH}$ 10.5 and $\mathrm{NaCl}-4 \%$ ) for morphological and cultural characters and in liquid medium for pot experiments. Gram staining was performed by Hucker and Conn's modified Gram staining method and motility by hanging drop method. The inoculum size used was 108 cells / $\mathrm{ml}$ and volume used was $100 \mathrm{ml}$ per pot containing 5 seeds of Triticum aestivum $L$. Soil $\mathrm{pH}$ and salinity was measured before experiment was carried out. The experiment was carried out in polyethylene pouches using five replicates in each pouch. Soil was sterilized at $1600 \mathrm{C}$ in a hot air oven for two hours each day for three consecutive days. The soil was then filled in pouches so as to fill about two third the capacity. The seeds of Triticum aestivum L. were washed with water, surface sterilized in $\mathrm{H} 2 \mathrm{O} 2$ for 4-5 min. and then washed with sterile distilled water. The seeds were sowed about $1-2 \mathrm{~cm}$. below the surface of the soil in the pouches. Fresh suspensions of moderately haloalkaliphilic Nitrogen fixers cultivated in Ashby's nitrogen free mannitol broth were centrifuged and the cell mass suspended in sterile saline was poured into the respective pouches. Uninoculated control was also run along with the experiment. After 15 days of cultivation, the plants were removed from the pouches. Shoot length and root length of the grown plant was measured. The roots were cut and removed. The plants (Shoots) were then dried at $700 \mathrm{C}$ in a hot air oven till constant weight measured. Pesticides may adversely affect the growth of nitrogen fixing bacteria. Hence, four commonly used chemical pesticides such as Endosulfon, Thiomethaxan, M-45 and Glycophosphate were used to test the effect of pesticides on the obtained isolates [4]. Different concentrations of every pesticide were prepared 
and added in Ashby's nitrogen free solid medium after sterilization. Plates were poured and loopful of the each culture was inoculated in each solidified plate containing increasing concentration of the respective pesticide. Plates were incubated at room temperature for 48 hours and appearance of growth was checked and reported. Effect of salt $(\mathrm{NaCl})$ concentration on the isolates was seen by inoculating loopful culture of each isolate on Ashby's nitrogen free Agar containing variable concentrations of $\mathrm{NaCl}$ on separate plates ranging from $1 \%$ - $20 \%$ respectively. The plates were incubated at room temperature for 48-72 hours. Presence of growth was observed and reported.

\section{Results and Discussion}

Microscopic observations of the six isolates conducted in our laboratory revealed the four isolates to be bacteria and the remaining two to be actinomycetes. The morphological and cultured characters of the isolates are depicted in Table No. 1. Four bacteria and two actinomycetes were used in the pot trial experiments. The results of which are presented in Table No. 2. From Table No. 2 it is evident that as far as dry mass of the plants is concerned the actinomycetes are much superior to the bacteria although the latter are not too far behind. But considering the length of the plants, bacteria, especially isolates $B$ and $C$ are the best. Results of pesticide resistance potential of the isolates to four different chemical pesticides are presented in tables 3-6. The results of six isolates showing growth upto $10 \% \mathrm{NaCl}$ concentration on Ashby's Nitrogen Free Mannitol Agar are represented in table No. 7.

\section{Conclusion}

From dry mass of plants it is concluded that haloalkaliphilic nitrogen fixing bacteria help to improve the plant growth in saline soil. The above mentioned diazotrophs may be used for reclamation of saline soils.

\section{Acknowledgements}

The authors are thankful to Principal and Management of College for providing the facilities for this Research work.

\section{References}

[1] Alexander M. (1977) J Wiley and sons, Inc., $287-304$.

[2] Thakker C.D., Ranade D. R. (2002) Current Science. 82, 4.

[3] Somawanshi R.B., Kadu P.P., Tamboli B.D., Patil Y.M., Bhakare B.D. (1994) Mahatma Phule Agricultural University, MPKV. EXTN PUB No. 284, 235 - 239.

[4] Subbarao N.S. (1999) In "Soil Microbiology" 4th edition published by Raju Primlani for Oxford and IBH publishing Co. Pvt., 24,219.116-151. 
Table 1- Colonial and Morphological Characters of the Isolates.

\begin{tabular}{|c|c|c|c|c|c|c|}
\hline Colonial and & Isolates & & & & & \\
\hline $\begin{array}{l}\text { Morphological } \\
\text { Characters }\end{array}$ & & $B$ & C & $\mathrm{W}_{2}$ & SE - I & $E-I$ \\
\hline Size $(\mathrm{mm})$. & 1 & 1 & 1 & 3 & 2 & 1 \\
\hline Shape & Circular & Circular & Circular & Circular & Circular & Circular \\
\hline Colour & Colourless & Colourless & Colourless & Colourless & White & White \\
\hline Margin & Entire & Entire & Entire & Entire & Irregular & Irregular \\
\hline Elevation & Convex & Raised & Raised & Convex & Flat & Flat \\
\hline Opacity & Opaque & Opaque & Opaque & Opaque & Opaque & Opaque \\
\hline Consistency & Mucoid & Mucoid & Mucoid & Mucoid & Dry & Dry \\
\hline Gram nature & $\begin{array}{l}\text { Gram negative } \\
\text { Rods }\end{array}$ & $\begin{array}{l}\text { Gram negative } \\
\text { Rods }\end{array}$ & $\begin{array}{l}\text { Gram negative } \\
\text { Rods }\end{array}$ & $\begin{array}{l}\text { Gram negative } \\
\text { Rods }\end{array}$ & $\begin{array}{l}\text { Gram positive } \\
\text { Filaments }\end{array}$ & $\begin{array}{l}\text { Gram positive } \\
\text { Filaments }\end{array}$ \\
\hline Motility & Non motile & Non motile & Non motile & Non motile & Non motile & Non motile \\
\hline
\end{tabular}

Table 2- Results of pot experiments performed in Polyhouse.

\begin{tabular}{|l|l|l|l|}
\hline \multirow{2}{*}{ Isolate } & Length $(\mathrm{cm}$.$) Mean of replicates$ & \multirow{2}{*}{ Dry mass (gm.) } \\
\cline { 2 - 4 } & Shoot & Root & \\
\hline Bacteria & 8 & & 0.010 \\
\hline $\mathrm{A}$ & 8 & 6 & 0.009 \\
\hline $\mathrm{B}$ & 12.5 & 5 & 0.009 \\
\hline $\mathrm{C}$ & 10.2 & 4.5 & 0.008 \\
\hline $\mathrm{W}_{2}$ & 5.22 & 4.14 & \\
\hline Actinomycetes & & & 0.014 \\
\hline SE - I & 9.68 & 5.32 & 0.012 \\
\hline E - I & 9.50 & 3 & 0.003 \\
\hline Control & 4.25 & 2.5 & 100 \\
\hline
\end{tabular}

Table 3- Table showing pesticide resistance potential of the isolates to different concentrations of Endosulfon.

\begin{tabular}{|l|l|l|l|l|l|}
\hline Sr. & Isolate & \multicolumn{5}{l|}{ Endosulfon Concentration $(\mathrm{mg} / 100 \mathrm{ml})$} \\
\cline { 3 - 6 } No. & Code & 250 & 500 & 750 & 800 \\
\hline 1 & $\mathrm{~A}$ & + & + & + & - \\
\hline 2 & $\mathrm{~B}$ & + & + & + & - \\
\hline 3 & C & + & + & + & - \\
\hline 4 & W 2 & + & + & + & - \\
\hline 5 & E-I & + & + & + & - \\
\hline 6 & SE-I & + & + & + & - \\
\hline
\end{tabular}

Table 4- Table showing pesticide resistance potential of the isolates to different concentrations of Thiomethoxan.

\begin{tabular}{|c|c|c|c|c|c|c|c|c|}
\hline \multirow{2}{*}{$\begin{array}{l}\text { Sr. } \\
\text { No. }\end{array}$} & \multirow{2}{*}{$\begin{array}{l}\text { Isolate } \\
\text { Code }\end{array}$} & \multicolumn{7}{|c|}{ Thiomethoxan Concentration (mg/100ml) } \\
\hline & & 250 & 500 & 750 & 1000 & 1250 & 1750 & 2000 \\
\hline 1 & $\mathrm{~A}$ & + & + & + & + & + & & \\
\hline 2 & $\mathrm{~B}$ & + & + & + & + & + & & \\
\hline 3 & $\mathrm{C}$ & + & + & + & + & & 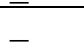 & \\
\hline 4 & W2 & + & + & + & + & 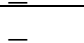 & - & 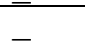 \\
\hline 5 & $\mathrm{E}-\mathrm{I}$ & + & + & + & + & & & \\
\hline 6 & SE-1 & + & + & + & + & 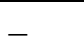 & 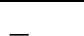 & 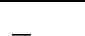 \\
\hline
\end{tabular}

Table 5-: Table showing pesticide resistance potential of the isolates to different concentrations of $M-45$.

\begin{tabular}{|l|l|l|l|l|l|}
\hline Sr. & \multirow{2}{*}{ Isolate Code } & \multicolumn{4}{|l|}{ M-45 Concentration $(\mathrm{mg} / 100 \mathrm{ml})$} \\
\cline { 3 - 7 } & & 250 & 500 & 750 & 1000 \\
\hline 1 & A & + & - & - & - \\
\hline 2 & B & + & - & - & - \\
\hline 3 & C & + & - & - & - \\
\hline 4 & W2 & + & - & - & - \\
\hline 5 & E-I & + & - & - & - \\
\hline 6 & SE-I & + & - & - & - \\
\hline
\end{tabular}


Table 6- Table showing pesticide resistance potential of the isolates to different

\begin{tabular}{|l|l|l|l|l|l|l|l|}
\hline Sr. & Isolate & \multicolumn{6}{l|}{ Glyophosphate Concentration (mg/100ml) } \\
\cline { 3 - 9 } No. & Code & 250 & 500 & 750 & 1000 & 1250 & 1750 \\
\hline 1 & A & + & + & + & + & + & - \\
\hline 2 & B & + & + & + & + & + & - \\
\hline 3 & C & + & + & + & - & + & - \\
\hline 4 & W2 & + & + & + & + & + & - \\
\hline 5 & E-I & + & + & + & + & - & - \\
\hline 6 & SE-I & + & + & + & + & - & - \\
\hline
\end{tabular}

Table 7- Table showing tolerance of isolates to different $\mathrm{NaCl}$ concentrations.

\begin{tabular}{|c|c|c|c|c|c|c|c|c|c|c|c|c|c|c|c|c|c|c|c|c|c|}
\hline \multirow{2}{*}{$\begin{array}{l}\text { Sr. } \\
\text { No. }\end{array}$} & \multirow{2}{*}{$\begin{array}{l}\text { Isolate } \\
\text { Code }\end{array}$} & \multicolumn{20}{|c|}{$\mathrm{NaCl}$ Concentration in \% } \\
\hline & & 1 & 2 & 3 & 4 & 5 & 6 & 7 & 8 & 9 & 10 & 11 & 12 & 13 & 14 & 15 & 16 & 17 & 18 & 19 & 20 \\
\hline 1 & $\mathrm{~A}$ & + & + & + & + & + & + & + & + & + & + & - & - & - & - & - & - & - & - & - & - \\
\hline 2 & $\mathrm{~B}$ & + & + & + & + & + & + & + & + & + & + & - & - & - & - & - & - & - & - & - & - \\
\hline 3 & $\mathrm{C}$ & + & + & + & + & + & + & + & + & + & + & - & - & - & - & - & - & - & - & - & - \\
\hline 4 & W2 & + & + & + & + & + & + & + & + & + & + & - & - & - & - & - & - & - & - & - & - \\
\hline 5 & $\mathrm{E}-1$ & + & + & + & + & + & + & + & + & + & + & - & - & - & - & - & - & - & - & - & - \\
\hline 6 & SE-1 & + & + & + & + & + & + & + & + & + & + & - & - & - & - & - & - & - & - & - & - \\
\hline
\end{tabular}

